\title{
FOR USE IN
}

\section{AFRICA}

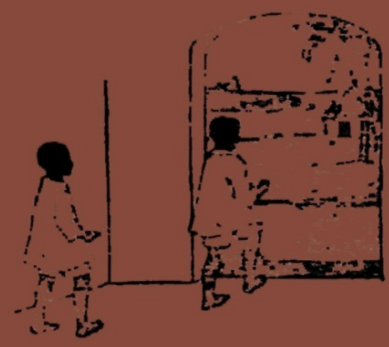

THE African Life series is lesigned to help the African child in learning to speak and read English. The material, which is taken from his own surroundings, comes within the limits of his experience. The method behind the books is 'direct', based upon the principles of see, say, do. Its purpose is to enable the child to think and to express his thoughts in simple English, ielated to the world in which he lives. A Teachers' Manual discusses the classroom development of material in the Readers.

\section{A F R I CAN L I F E S E R I E S}

PRIMER

FIRST READER

SECOND READER

THIRD READER

TEACHERS' MANUAL
15. Id.

Is. $4 d$.

1s. $6 d$.

1s. $6 d$.

2s.

\section{GINN AND COMPANY LTD. QUEEN SQUARE, LONDON, W.C. I}

First printed ry45. Refprinted lithusraphically 1051 at the Lniversity Press, Oxfurd by Charles Batev, Printer to the Lniversity. 


\section{THE STANDARD BANK OF SOUTH AFRICA \\ LIMITED}

Bankers to the Imperial Government in South Africa; and to the Governments of Southern Rhodesia, Northern Rhodesiu, Nyasaland, and Tanganyika

Capital Authorized and Subscribed . . fro,000,000 Capital Paid Up . . . . . . $\$ 2,500,000$ Reserve Fund . . . . . . . . $\$ 3,000,000$

IO CLEMENTS LANE, LOMBARD STREET \& 77 KING WILLIAM STREET, LONDON, E.C. 4

LONDON WALL Branch, 63 London Wall, E.C. 2

WEST-END Branch, 9 Northumberland Avenue, W.C.2

NEW YORK AGENCY, 67 Wall Street

Over 390 Branches, Sub-Branches, and Agencies in SOUTH, EAST, and CENTRAL AFRICA

Banking Business of every description transacted at all Branches and Agencies

\section{THE \\ RHODES-LIVINGSTONE INSTITUTE, LIVINGSTONE}

investigates the social and psychological problems of man in British Central Africa

The Institute publishes-

(1) The Rhodes-Livingstone Papers (to date Nos 1-10), which are general suciolugical analyses.

(2) Communications of the Rhodes-Livingstone Institute, in which material which is too detailed to appear in series (1), but which is of scientific and local value, is roneoed.

(3) The Rhodes-Livingstone Museum Occaslonal Papers, which deal with the ethnological, historical, technological, and archaeological collections in the Rhodes-Livingstone Museum.

(4) The Journal of the Rhodes-Livingstune Institute. in which man's problems in Central Africa, and what is known about them, what research is being done and needs to be done on them, and how they are being faced, are set out simply but with scientific accuracy.

$$
\sim
$$

Members, who receive all publications and may use the library, pay an annual subscription of 10 s. a year.

$$
\text { For details write to }
$$

P.O. BOX 195, LIVINGSTONE, N.R.
Write to

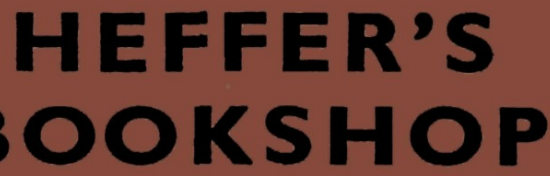

Heffer's will advise you in the selection of books, help you to find out-of-print books, and will welcome inquiries of all kinds. Catalogues of books in all fields of literature including lists of books in new condition offered at reduced prices are sent free on request.

Heffer's buy books and journals and will pay generous prices for rare items.

Especially wanted :-

Complete sets of Africa.

Journal of the Royal African Society.

Sudan Notes and Queries.

Encyclopaedia of Islam.

Lane: Arabic Lexicon.

W. HEFFER \& SONS, Ltd. CAMBRIDGE ENGLAND 